University of Nebraska - Lincoln

DigitalCommons@University of Nebraska - Lincoln

Faculty Publications: Department of

Entomology

Entomology, Department of

June 2006

\title{
Effect of Bacillus thuringiensis Cry3Bb1 Protein on the Feeding Behavior and Longevity of Adult Western Corn Rootworms (Coleoptera: Chrysomelidae)
}

Timothy M. Nowatski

Pioneer Hi-Bred International, P.O. Box 1004, Johnston, IA

Xugou Zhou

University of Florida, Gainesville, FL

Lance J. Meinke

University of Nebraska-Lincoln, Imeinke1@unl.edu

Ty Vaughn

Monsanto Co., 700 Chesterfield Pkwy North, St. Louis, MO 63198

Blair Siegfried

University of Nebraska-Lincoln, bsiegfried1@ufl.edu

Follow this and additional works at: https://digitalcommons.unl.edu/entomologyfacpub

Part of the Entomology Commons

Nowatski, Timothy M.; Zhou, Xugou; Meinke, Lance J.; Vaughn, Ty; and Siegfried, Blair, "Effect of Bacillus thuringiensis Cry3Bb1 Protein on the Feeding Behavior and Longevity of Adult Western Corn Rootworms (Coleoptera: Chrysomelidae)" (2006). Faculty Publications: Department of Entomology. 50.

https://digitalcommons.unl.edu/entomologyfacpub/50

This Article is brought to you for free and open access by the Entomology, Department of at DigitalCommons@University of Nebraska - Lincoln. It has been accepted for inclusion in Faculty Publications: Department of Entomology by an authorized administrator of DigitalCommons@University of Nebraska - Lincoln. 


\title{
Effect of Bacillus thuringiensis Cry3Bb1 Protein on the Feeding Behavior and Longevity of Adult Western Corn Rootworms (Coleoptera: Chrysomelidae)
}

\author{
TIMOTHY M. NOWATZKI, ${ }^{1}$ XUGUO ZHOU, ${ }^{2}$ LANCE J. MEINKE, TY VAUGHN, ${ }^{3}$ \\ AND BLAIR D. SIEGFRIED ${ }^{4}$
}

202 Plant Industry Building, Department of Entomology, University of Nebraska-Lincoln, Lincoln, NE 68583-0816

J. Econ. Entomol. 99(3): 927-930 (2006)

\begin{abstract}
The first transgenic corn hybrids expressing the Bacillus thuringiensis (Bt) Cry3Bb1 protein to control corn rootworm (Diabrotica spp.) larvae were registered for commercial use in 2003. This study was conducted to investigate the effect of Cry3Bbl protein in combination with a cucurbitacin bait on adult feeding and longevity of both organophosphate-resistant and -susceptible western corn rootworms, Diabrotica virgifera virgifera LeConte (Coleoptera: Chrysomelidae). In choice and no-choice tests, possible repellency to the Bt protein was quantified by comparing beetle consumption of cellulose disks treated with three concentrations of $\mathrm{Bt}$ in combination with a feeding stimulant (Invite EC) to disks treated with stimulant alone. A lethal-time assay also was conducted to examine survival of beetles exposed to Bt protein in their diet. Results from these assays indicate that adult rootworms are not significantly deterred by the presence of $\mathrm{Cry} 3 \mathrm{Bbl}$ on the treated discs and that ingestion of toxin does not adversely affect adult longevity.
\end{abstract}

KEY WORDS western corn rootworm, transgenics, Cry3Bb1, behavior, survival

The first transgenic corn, Zea mays L., hybrids targeted to control corn rootworms (Diabrotica spp.) were registered for commercial use in 2003 (EPA 2003). Event MON863 hybrids express the Cry3Bb1 protein from Bacillus thuringiensis (Bt). Corn expressing the Cry3Bbl protein is intended to protect against larval injury from the western corn rootworm, $D i$ abrotica virgifera virgifera LeConte; northern corn rootworm, Diabrotica barberi Smith \& Lawrence; and Mexican corn rootworm, Diabrotica virgifera zeae Krysan \& Smith that all feed on and injure the roots. Although larval feeding on roots is the primary mechanism for exposure, concentrations of Cry3Bb1 protein (micrograms of protein per gram of fresh weight tissue) have been reported to range from 30 to 93 in the leaf, from 49 to 86 in grain, from 30 to 93 in pollen, and from 3.2 to 66 in roots (EPA 2003). Whole-plant expression of the protein suggests that adults will be exposed to the toxin through their feeding on the aboveground portions of the plant. Very little information is available, however, on how adult exposure to the protein might influence subsequent behavior and fitness. This information could be particularly important for event MON863, because the protein is expressed at a low-to-moderate dose, and significant

\footnotetext{
${ }^{1}$ Pioneer Hi-Bred International, P.O. Box 1004, Johnston, IA 50131

${ }^{2}$ Department of Entomology and Nematology, University of Florida, Gainesville, FL 32611.

${ }^{3}$ Monsanto Co., 700 Chesterfield Pkwy North, St. Louis, MO 63198.

${ }^{4}$ Corresponding author, e-mail: bsiegfriedl@unl.edu.
}

beetle emergence (17-62\%) has been reported from these hybrids (EPA 2003). Although Cry3Bbl has been suggested to have no effect on rootworm adults (Vaughn et al. 2005), there is little quantitative information available on potential effects on adults.

In this report, we describe results from a set of experiments designed to document the effect of purified Cry3Bbl protein on adult rootworm feeding and longevity. The protein was combined with a known feeding stimulant and arrestant for diabroticite beetles derived from a cucurbitacin bait (Schroder et al. 1998) to ensure consumption of the toxin and provide a means to evaluate repellency of the toxin in the presence of the arrestant and feeding stimulant.

\section{Materials and Methods}

Insect Populations. Beetles from two western corn rootworm populations (Gresham and Whitlock) were obtained from the USDA Northern Grain Insect Research Laboratory in Brookings, SD. Both colonies were initiated from at least 500 field-collected beetles and reared in the laboratory for at least five or six generations with at least 200,000 eggs collected at each generation. Previous studies had characterized the Gresham population (York County, Nebraska) as resistant both to methyl-parathion and carbaryl (Meinke et al. 1998), whereas the Whitlock population (South Dakota) was highly susceptible to both (L.J.M., unpublished). Beetles were maintained in 
Plexiglas cages at $22-25^{\circ} \mathrm{C}$ on a diet of fresh sweet corn ears and lettuce, Lactuca sativa $\mathrm{L}$. until the assays were conducted.

Test Substance. Purified Cry3Bb1 was obtained as a stock solution $(4 \mathrm{mg} / \mathrm{ml})$ of protein in $\mathrm{Na}_{2} \mathrm{CO}_{3}$ buffer, $\mathrm{pH}$ 10.3, from Monsanto Co. (St. Louis, MO) and stored at $-80^{\circ} \mathrm{C}$ until use. Protein dilutions for the assays were prepared in Invite EC (Florida Food Products Agrochemicals, Eustis, FL) that had previously been diluted 10-fold in double distilled $\mathrm{H}_{2} \mathrm{O}$ and chilled on ice. Invite is a semiochemical (cucurbitacin)-based bait formulated as an emulsifiable concentrate containing Hawkesbury watermelon juice, Citrullus vulgaris Schrad. Because cucurbitacins are known to stimulate compulsive feeding and arrestant responses in diabroticite beetles (Metcalf and Lampman 1989), Cry3Bb1 was diluted with Invite to ensure consumption of the $\mathrm{Bt}$ protein by the beetles.

Feeding Behavior Bioassays. No-choice and choice feeding assays were conducted to determine whether Cry3Bbl inhibited beetle feeding and attraction to the Invite formulation. Beetles were 10-16 and 12-18 d old when the no-choice and choice experiments, respectively, were conducted. Four treatments were evaluated, consisting of Invite alone, Invite $+10 \mu \mathrm{g} \mathrm{Bt} / \mathrm{g}$ disk, Invite $+100 \mu \mathrm{g} \mathrm{Bt} / \mathrm{g}$ disk, and Invite $+1000 \mu \mathrm{g}$ $\mathrm{Bt} / \mathrm{g}$ disk. The treatments of 10 and $100 \mu \mathrm{g} \mathrm{Bt} / \mathrm{g}$ disk were chosen to represent the range of Cry3Bbl reported to be expressed in the aboveground corn tissues (EPA 2003). The 1,000- $\mu \mathrm{g}$ treatment, $\approx 10$-fold higher than levels of Cry3Bbl reported in aboveground corn tissues, was included to determine whether any behavioral response could be detected. Each treatment was replicated 10 times. For each treatment, 20 $\mu \mathrm{l}$ of toxin/Invite solution was applied to the surface of a 13-mm-diameter cellulose membrane disk (pore size $0.45 \mu \mathrm{m}$, Pall Life Sciences, East Hills, NY) as described by Parimi et al. (2003). Air-dried disks were positioned on minuten pins above water-moistened filter paper in 9-cm-diameter petri dishes with a paraffin wax bottom. For no-choice tests, a single disk was placed in the center of each petri dish with two beetles of the same sex and population. For the choice test, two disks (one with Invite and one with Invite $+\mathrm{Bt}$ ) were arranged on opposite ends of each petri dish that each contained a single beetle. Petri dishes were placed in a growth chamber with constant lighting at a temperature of $22^{\circ} \mathrm{C}$. After 8 and $48 \mathrm{~h}$ of feeding, disks from the no choice and choice tests, respectively, were removed, and their surface areas were measured with a LI-COR 3000 leaf area meter (LI-COR, Lincoln NE).

Lethal-Time Bioassay. Rootworm adults, 15-21 d old, were confined in individual wells of bioassay trays (CD International, Pitman, NJ) containing $0.25 \mathrm{ml}$ of $1 \%$ agar, $1 \%$ agar containing Invite, or Invite $+\mathrm{Bt}$ protein at two concentrations (10 and $100 \mu \mathrm{g} \mathrm{Bt} / \mathrm{g}$ diet). All treatments contained $0.32 \%$ methyl paraben and $0.12 \%$ sorbic acid dissolved in water to minimize microbial contamination. For the treatments requiring Invite, $10 \%$ of the water used to prepare the agar was replaced with Invite. Preparation required heating the agar to a boil, cooling to $60^{\circ} \mathrm{C}$, and thoroughly mixing the Invite and purified Cry $3 \mathrm{Bb} 1$ protein into solution. Immediately after mixing, $0.25 \mathrm{ml}$ of diet was dispensed into each well and allowed to solidify. Individual beetles were confined in each well immediately after the agar solidified and covered with an adhesive lid (CD International). In total, 16 beetles were assayed per treatment for each population by gender combination. Beetle mortality, determined as the inability to move when prodded, was recorded daily until all beetles were dead. Trays were maintained in a growth chamber at $22^{\circ} \mathrm{C}$ and photoperiod of $16: 8$ (L:D) h.

Individual beetles exposed to the Invite/Cry3Bb1 mixture within the wells were tested for the presence of Cry3Bbl in whole body homogenates by using methods adapted from Spencer et al. (2003). Beetles that had died during a 24 -h period were collected and stored at $-20^{\circ} \mathrm{C}$. Individual beetles were homogenized in 1.5-ml microfuge tubes in $200 \mu \mathrm{l}$ of distilled water and a gene check strip (EnviroLogix, Portland, ME) was inserted into the sample. The strips were read at $30 \mathrm{~min}$ and confirmed at $24 \mathrm{~h}$ to determine whether the $\mathrm{Cry} 3 \mathrm{Bb}$ toxin was detected in the sample. Tests conduced on beetles exposed to either agar or to the Invite/agar treatments were never positive for the $\mathrm{Cry} 3 \mathrm{Bb}$ toxin.

Statistical Analyses. For the choice data, a consumption index (CI) was calculated for each treatment, where CI equals the surface area of the Invite control disk $(I)$ minus the surface area of the Invite $+\mathrm{Bt}$ $(B t)$-treated disk divided by $I$ and represents the percentage of Bt-treated disk area consumed relative to the Invite control $[\mathrm{CI}=(I-B t) / I \times 100]$. Consumption indices for treatments in the no-choice test were also calculated; however, the average area of the unfed control disk was substituted for $I$ in the above-mentioned equation. For both the choice and no-choice tests, analysis of variance (ANOVA) was used to test for treatment effects on CI; multiple pairwise comparisons of treatment means were performed using the Tukey-Kramer honestly significant difference test in SAS (SAS Institute 2001).

For the lethal time assay, mortality rates of beetles exposed to each diet treatment were described with a logistic model by using the probit procedure in SAS (SAS Institute 2001). Goodness-of-fit of the regression lines were determined from the $\chi^{2}$ test statistics (lack of fit indicated by significant $\chi^{2}$ value). Within a population and gender, the significance of differences among $\mathrm{LT}_{50}$ and $\mathrm{LT}_{90}$ values was indicated by nonoverlapping 95\% fiducial limits (FL) (Savin et al. 1977).

\section{Results and Discussion}

Choice Test. Results of the choice disc consumption rates are presented in Fig. 1. No significant differences between populations $(n=120, P=0.06)$, sexes $(n=$ $120, P=0.17)$ or Invite versus Invite $+\mathrm{Bt}(n=120$, $P=0.46$ ) were apparent (Mann-Whitney $U$ test; data not shown), so data were pooled for subsequent anal- 


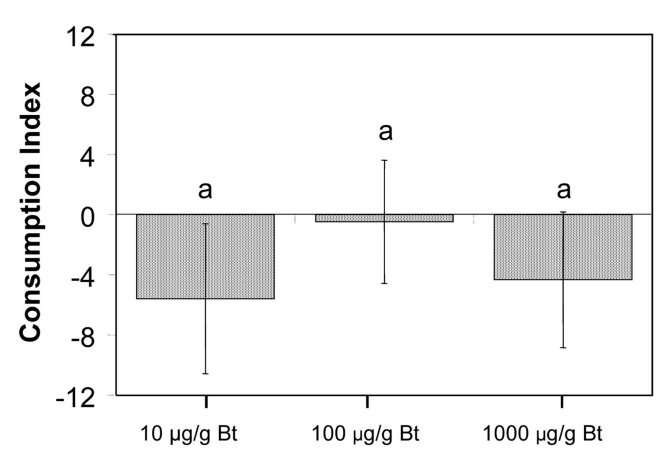

Fig. 1. Mean $( \pm \mathrm{SE})$ consumption indices of disks treated with three concentrations of purified Cry $3 \mathrm{Bb} 1$ protein combined with Invite by western corn rootworm adults in a choice assay. Consumption index indicates percentage of Bt-treated disc area consumed relative to discs treated with Invite alone $(n=40)$.

ysis. Although the mean consumption index for the Bt treatments indicated a slight preference (values slightly less than zero) for disks treated with Invite versus disks treated with Invite $+\mathrm{Bt}$, there were no significant differences $(F=0.34 ; \mathrm{df}=2,115 ; P=0.71)$ among the three Bt concentrations tested (Fig. 1).

No-Choice Test. Results from ANOVA indicated no significant differences in disk areas consumed between populations $(F=2.22 ; \mathrm{df}=1,145 ; P=0.14)$ or sexes $(F=1.34 ; \mathrm{df}=1,145 ; P=0.25)$, and data were pooled for subsequent analyses. There were no significant differences $(F=0.21 ; \mathrm{df}=3,145 ; P=0.89)$ in the mean consumption index among the four treatments, indicating that in a no-choice situation, beetles fed equally on disks treated with Invite + purified Cry3Bbl protein compared with disks treated with Invite alone (Fig. 2).

Lethal-Time Assay. In general, the exposure to the Cry3Bb1 toxin did not seem to negatively impact sur-

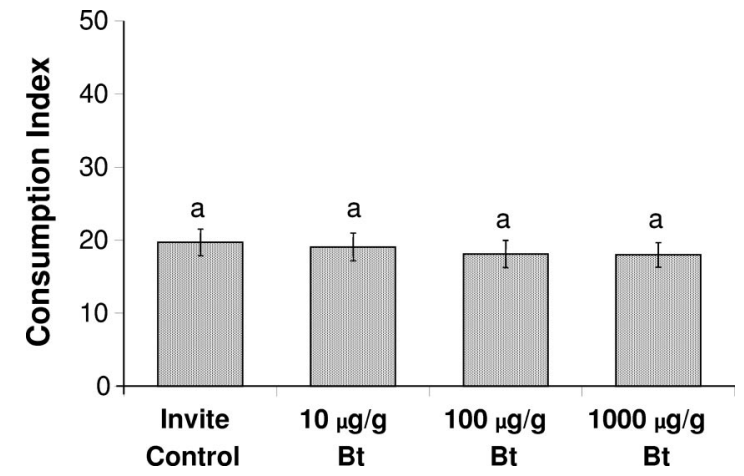

Fig. 2. Mean $( \pm \mathrm{SE})$ consumption indices of disks treated with Invite alone (Control) and three concentrations of purified Cry3Bb1 protein combined with Invite by western corn rootworm adults in a no-choice assay. Consumption index represents percentage of treated disk area consumed relative to the mean area of unfed, control disks $(n=40)$.

vival time (Table 1). Results of assays to detect the presence of the Cry3Bb1 toxin in individual beetles by using gene check strips indicated that although toxin was not detected in every individual, a high percentage $(>50 \%)$ tested positive for the presence of toxin even at the lowest concentration (data not shown), thereby confirming exposure to the toxin. The $\mathbf{L T}_{50}$ values for both populations were generally shortest for those individuals fed agar alone, although the effect was more pronounced in males. The presence of Invite seemed to enhance the nutritional value of the agar as LT values were generally longer for both populations (Table 1). The presence of Cry3Bbl toxin at both concentrations further enhanced survival time for males of both populations, suggesting that the toxin had been used as a source of nutrition and was clearly not having a significant detrimental effect. However, results for females were not consistent across treat-

Table 1. Susceptibility of male and female adult western corn rootworm to purified Cry3Bbl Bt protein incorporated at two concentrations ( 10 and $100 \mu \mathrm{g} \mathrm{Bt/g}$ diet $)$ into agar-based diet $(n=16)$

\begin{tabular}{|c|c|c|c|c|c|c|c|}
\hline $\mathrm{Pop}^{a}$ & Diet treatment & Slope $( \pm \mathrm{SE})$ & $\mathrm{LT}_{50}(95 \% \mathrm{FL})^{b}$ & $\mathrm{LT}_{90}(95 \% \mathrm{FL})^{b}$ & $\chi^{2 c}$ & $\mathrm{df}$ & $P>\chi^{2}$ \\
\hline \multirow[t]{4}{*}{ Gresham male } & Agar & $1.3(0.2)$ & $4.9(4.54-5.44)$ & $6.6(6.09-7.58)$ & 2.15 & 26 & 1.00 \\
\hline & Invite EC & $0.3(0.02)$ & $9.9(8.89-10.90)$ & $18.2(16.71-20.06)$ & 6.22 & 28 & 1.00 \\
\hline & $10 \mathrm{Bt}$ & $0.2(0.02)$ & $16.5(15.28-17.73)$ & $28.1(25.92-30.95)$ & 13.94 & 28 & 0.98 \\
\hline & $100 \mathrm{Bt}$ & $0.3(0.03)$ & $20.1(19.11-21.17)$ & $28.3(26.58-30.78)$ & 5.06 & 20 & 0.99 \\
\hline \multirow[t]{4}{*}{ Gresham female } & Agar & $0.5(0.05)$ & $14.4(13.65-15.05)$ & $18.6(17.64-19.89)$ & 5.05 & 26 & 1.00 \\
\hline & Invite EC & $0.2(0.02)$ & $22.4(21.14-23.69)$ & $34.2(31.89-37.25)$ & 17.21 & 30 & 0.97 \\
\hline & $10 \mathrm{Bt}$ & $0.2(0.02)$ & $20.3(19.22-21.50)$ & $30.8(28.89-33.26)$ & 16.90 & 31 & 0.98 \\
\hline & $100 \mathrm{Bt}$ & $0.2(0.01)$ & $15.9(14.66-17.17)$ & $28.5(26.39-31.20)$ & 7.06 & 32 & 1.00 \\
\hline \multirow[t]{4}{*}{ Whitlock male } & Agar & $0.9(0.13)$ & $7.1(6.57-7.64)$ & $9.5(8.79-10.54)$ & 2.94 & 30 & 1.00 \\
\hline & Invite EC & $0.2(0.02)$ & $10.8(9.77-11.86)$ & $19.7(18.26-21.68)$ & 14.41 & 33 & 0.99 \\
\hline & $10 \mathrm{Bt}$ & $0.3(0.03)$ & $15.3(14.34-16.25)$ & $22.9(21.53-24.69)$ & 10.36 & 28 & 0.99 \\
\hline & $100 \mathrm{Bt}$ & $0.2(0.02)$ & $16.1(14.98-17.11)$ & $24.9(23.35-26.97)$ & 16.30 & 26 & 0.93 \\
\hline \multirow[t]{4}{*}{ Whitlock female } & Agar & $0.6(0.06)$ & $12.1(11.39-12.75)$ & $15.9(15.05-17.25)$ & 6.24 & 25 & 0.99 \\
\hline & Invite EC & $0.3(0.02)$ & $11.3(10.22-12.29)$ & $19.6(18.11-21.48)$ & 7.34 & 28 & 1.00 \\
\hline & $10 \mathrm{Bt}$ & $0.4(0.04)$ & $16.8(16.02-17.55)$ & $21.8(20.78-23.27)$ & 8.86 & 24 & 0.99 \\
\hline & $100 \mathrm{Bt}$ & $0.2(0.02)$ & $11.5(10.38-12.58)$ & $21.3(19.72-23.46)$ & 14.55 & 31 & 0.99 \\
\hline
\end{tabular}

\footnotetext{
${ }^{a}$ Individual beetles were confined in wells of bioassay trays containing $250 \mu \mathrm{l}$ of an agar-based diet treated with agar alone, Invite EC, or Invite EC+ purified Cry3Bbl protein at two concentrations (10 and $100 \mu \mathrm{g} \mathrm{Bt/g} \mathrm{diet).}$

${ }^{b}$ Lethal time (days) of adult western corn rootworms when confined on one of four agar-based diet treatments with $95 \%$ FLs at the $50 \%$ $\left(\mathrm{LT}_{50}\right)$ and $90 \%\left(\mathrm{LT}_{90}\right)$ levels of probit mortality.

${ }^{c}$ Chi-square goodness-of-fit statistics as determined by fitting the logistic model with the probit procedure in SAS (SAS Institute 1999).
} 
ments and populations. There were no apparent reductions in survival time of females exposed to Invite + Cry3Bbl relative to survival on agar alone for either population. However, for Gresham females exposed to the higher concentration of toxin, the $\mathrm{LT}_{50}$ was similar to agar alone and significantly lower than the agar + Invite treatment. In a no-choice situation, consumption of high concentrations $(100 \mu \mathrm{g} / \mathrm{g}$ diet $)$ of Cry3Bbl seemed to reduce adult female longevity in the Gresham population. Differences between populations may indicate that such effects are dependent on the reproductive and physiological condition at the time of the assay. However, in general there does not seem to be a strong negative impact of the protein on adult longevity in any of the comparisons.

Within the context of beetle age structure included in each assay, the consumption of purified Cry3Bbl Bt protein at concentrations comparable with those reported for aboveground tissues of transgenic corn plants in combination with the feeding stimulant Invite EC did not significantly influence feeding behavior or relative longevity of western corn rootworm adults. It seems likely that physiological differences between adult rootworms and larvae, such as differences in gut $\mathrm{pH}$ and the presence of activating/degrading proteases, are likely to contribute to the apparent lack of susceptibility in adult rootworms.

These data suggest that western corn rootworm adults will exhibit similar feeding behaviors when encountering transgenic (expressing Cry $3 \mathrm{Bb}$ Bt protein) or nontransgenic corn plants in the field and that it is unlikely that $\mathrm{Cry} 3 \mathrm{Bb} \mathrm{Bt}$ protein in transgenic plants will have significant effects on adults that might impact resistance management recommendations. For example, if the Cry3Bbl protein were repellent to adult corn rootworms, there may be a decrease in the number of beetles from refuge fields entering the transgenic field. This would decrease the effectiveness of the refuge acres. These results support the general lack of fitness effects observed by Al-Deeb and Wilde (2005) for adult rootworms that were maintained on Cry3Bb1-expressing corn plants as larvae or adults. However, similar experiments that compare response to Cry3Bbl-expressing plant tissue with nonexpressing tissue should be conducted over the entire life cycle to confirm the lack of response to adult corn rootworms.

\section{Acknowledgments}

We acknowledge the contributions M. Tiller for data analysis and enzyme-linked immunosorbent assay testing. This research was supported through a grant to B.D.S. and L.J.M. by Monsanto Co. This is journal series paper 14909, Nebraska Agricultural Research Division and contribution no. 1206 of the Department of Entomology, University of Nebraska.

\section{References Cited}

Al-Deeb, M. A., and G. E. Wilde. 2005. Effect of Bt corn expressing the Cry3Bb1 toxin on western corn rootworm (Coleoptera: Chrysomelidae) biology. J. Kans. Entomol. Soc. 78: 142-152.

[EPA] Environmental Protection Agency. 2003. Bacillus thuringiensis Cry3Bb1 protein and the genetic material necessary for its production (vector ZMIR13L) in event MON863 corn fact sheet. EPA publication no. 730-F-0301.

Parimi, S., L. J. Meinke, T. M. Nowatzki, L. D. Chandler, B. W. French, and B. D. Siegfried. 2003. Toxicity of insecticide-bait mixtures to insecticide resistant and susceptible western corn rootworms (Coleoptera: Chrysomelidae). Crop Prot. 22: 781-786.

Meinke, L. J., B. D. Siegfried, R. J. Wright, and L. D. Chandler. 1998. Adult susceptibility of Nebraska western corn rootworm (Coleoptera: Chrysomelidae) populations to selected insecticides. J. Econ. Entomol. 91: 954-600.

Metcalf, R. L., and R. L. Lampman. 1989. The chemical ecology of diabroticites and Cucurbitaceae. Experientia 45: $240-247$.

Savin, N. E., J. L. Robertson, and R. M. Russell. 1977. A critical evaluation of bioassays in insecticide research: likelihood ratio tests of dose-mortality regression. Bull. Entomol. Soc. Am. 23: 27-266.

SAS Institute. 2001. SAS/STAT user's guide. SAS Institute, Cary, NC.

Schroder, R.F.W., A. B. DeMilo, C. J. Lee, and P.A.W. Martin. 1998. Evaluation of water-soluble bait for corn rootworm (Coleoptera: Chrysomelidae). J. Econ. Entomol. 94: 892897.

Spencer, J. L., T. R. Mabry, and T. T. Vaughn. 2003. Use of transgenic plants to measure insect herbivore movement. J. Econ. Entomol. 96: 1738-1749.

Vaughn, T. T., T. Cavato, G. Brar, T. Coombe, T. DeGooyer, S. Ford, M. Groth, A. Howe, S. Johnson, K. Kolacz, et al. 2005. A method of controlling corn rootworm feeding using a Bacillus thuringiensis protein expressed in transgenic maize. 2005. Crop Sci. 45: 931-938.

Received 7 September 2005; accepted 20 January 2006 
This article is the copyright property of the Entomological Society of America and may not be used for any commercial or other private purpose without specific written permission of the Entomological Society of America. 